\title{
OPTIMAL ACQUISITION POLICY IN REMANUFACTURING SYSTEMS WITH QUANTITY DISCOUNT AND CARBON TAX SCHEME
}

\author{
Cheng-Hu Yang, Xiao-Ying Bao, Cong Song, Hai-Bo Liu
}

Original scientific paper

High uncertainty and variability of acquirable cores can lead to some difficulties of operations management in the remanufacturing process. Two acquisition models with quantity discount and carbon tax scheme were established to analyze the effect of quality variability and condition uncertainty and to reduce these difficulties. In the first model, quality variability was considered. The optimal acquisition policy was determined by a single closed-form expression because the average cost of remanufactured products is independent of the acquisition quantity for a given discount segment. In the second model, both quality variability and condition uncertainty were considered. The properties of the model were analyzed, and a single algorithm was developed to obtain the optimal acquisition policy based on the bisection method. Finally, numerical simulation examples were provided to explore the effect of quantity discount on the optimal acquisition policy. Results show that the quantity discount schedule impels remanufacturers to acquire more cores and enhances the chances of remanufacturers to select the best cores. Moreover, the total expected cost decreases, especially in the case with both quality variability and condition uncertainty. The proposed model can effectively solve the acquisition problem in remanufacturing systems.

Keywords: carbon emission; core acquisition; remanufacturing; quantity discount; quality variability

Optimalna politika akvizicije u sustavima preradbe s diskontom na količinu i planom poreza na ugljik

Izvorni znanstveni članak

Velika nesigurnost i promjenljivost akvizicijskih temelja, mogu stvoriti poteškoće kod upravljanja operacijama u procesu preradbe. Postavljena su dva modela akvizicije s popustom na količinu i planom poreza na ugljik u svrhu analize učinka promjenljivosti kvalitete i nesigurnosti uvjeta i smanjenja tih problema. U prvom se modelu razmatrala promjenljivost kvalitete. Optimalna politika akvizicije određena je pojedinačnim izrazom zatvorenog oblika jer prosječna cijena prerađenog proizvoda ne ovisi o dobivenoj količini za dati segment diskonta. U drugom su modelu uzeti u obzir i promjenljivost kvalitete i nesigurnost uvjeta. Analizirana su svojstva modela i razvijen je algoritam za postizanje optimalnog načina akvizicije na temelju metode bisekcije. Konačno, dani su primjeri numeričke simulacije kako bi se istražio učinak diskonta na količinu na optimalni način akvizicije. Rezultati pokazuju da se politikom diskonta na količinu prerađivači potiču na dobivanje više osnova i povećavaju im se mogućnosti da izaberu najbolju osnovu. Štoviše, smanjuje se ukupno očekivani trošak, naročito kad se radi i o promjenljivosti kvalitete i o nesigurnosti uvjeta. Predloženi model može uspješno riješiti problem akvizicije u prerađivačkim sustavima.

Ključne riječi: diskont na količinu; ispuštanje ugljika; preradba; promjenljivost kvalitete; temeljna akvizicija

\section{Introduction}

With respect to the current competitive business situation and the environmental protection concern, remanufacturing is an effective way to maximize value creation in the entire product life cycle and reduce the emissions of carbon dioxide $\left(\mathrm{CO}_{2}\right)$ and other heattrapping gases $[1,2]$. In practice, firms develop remanufacturing businesses to obtain social, economic, and environmental benefits [3, 4].

According to Sundin, a typical remanufacturing process includes core acquisition, disassembly, inspection, sorting, cleaning, reprocessing, reassembly, checking and testing (Fig. 1) [5].

Core acquisition has been considered as the key input to assess the potential economic attractiveness of remanufacturing activities. During acquisition, high uncertainty and variability of acquirable cores (i.e. quantity, quality and time) are crucial features that pose great challenges to remanufacturers $[6,7]$. Specifically, uncontrollable return makes the production planning and control of remanufacturing systems difficult $[8 \div 11]$. Moreover, the remanufacturer can increase its selectivity as more cores are acquired and select the best cores to reduce remanufacturing costs [9]. The remanufacturer is motivated to take measures to collect more cores. Quantity discount, as a frequently used promotion policy, encourages brokers or collectors to provide more cores.

In addition, environmental burdens (i.e. energy consumption, material consumption, and carbon emission) have significant effects on remanufacturing systems. The remanufacturer should incorporate environmental factors into remanufacturing decisions [12]. Thus, the remanufacturer should consider the tradeoff of between environmental and economic benefits when acquiring cores.

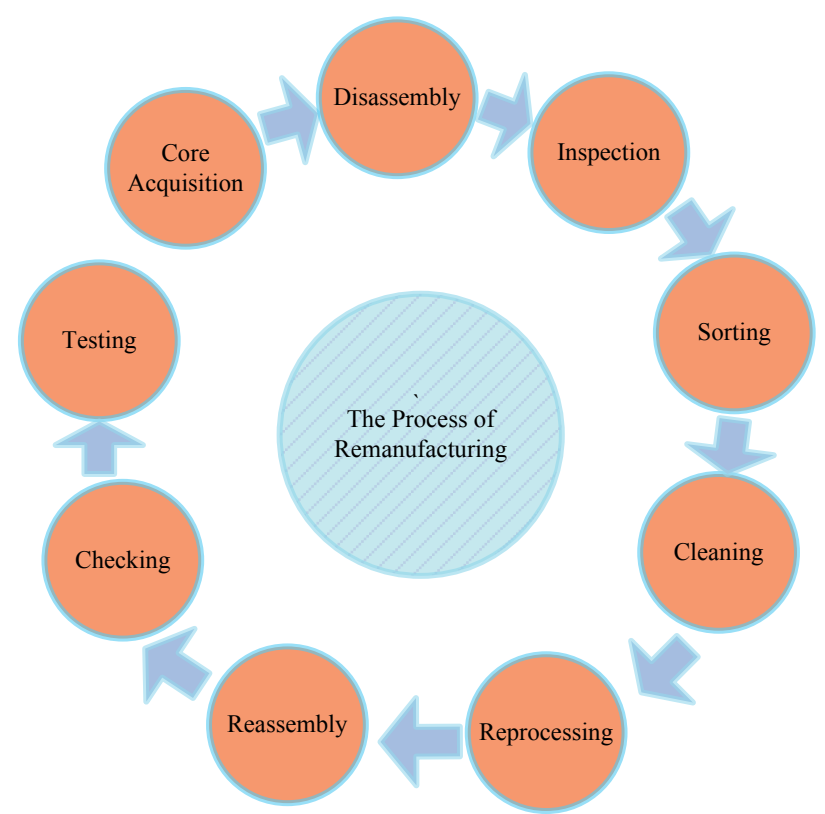

Figure 1 Typical remanufacturing process 
According to the above analysis, this paper examines a core acquisition problem on the highly variable quality of acquirable cores. Subsequently, the effects of quantity discount and environmental burdens are considered.

The rest of this paper is organized as follows. In Section 2, the related literature review is discussed, and the differences between our paper and the literature are analyzed. In Section 3, the model with quality variability is developed using a nonlinear mixed integer programming model. The optimal solutions are analyzed and derived. The extension model with both condition uncertainty and the quality variability is also developed in this section. In Section 4, numerical simulation examples are provided to illustrate the model and the approach with managerial insights. Section 5 concludes the paper with future research directions.

\section{State of the art}

Core acquisition, as one of the key steps in remanufacturing, has attracted considerable attention from researchers. A number of researchers have discussed various optimal operational policies in core acquisition, and proposed that positive core acquisition could influence or control the quality and quantity of acquirable cores $[13 \div 19]$.

Scholars have focused on the effect of core quality on the optimal policies of core acquisition owing to the inherent variability of acquirable cores. The effect is mainly discussed from the viewpoint of both condition uncertainty and quality variability.

The number of cores to be remanufactured in the uncertainty condition is stochastic for a certain acquisition quantity in core acquisition (i.e., the proportional yield is stochastic). Some researchers have discussed how core acquisition is affected by condition uncertainty. For example, Zhou and $\mathrm{Yu}$ studied the optimal acquisition policy in a reverse supply chain, in which the proportional yields are uncertain at two possible correlated collection sites [20]. Zikopoulos and Tagaras analyzed the optimal quantity of core procurement and remanufacturing in a two-stage reverse supply chain, and discussed the optimal application condition of quick sorting [21]. Van Wassenhove and Zikopoulos highlighted the effect of quality overestimation on the optimal acquisition decisions under the deterministic and stochastic demand [2]. Li et al. examined a coordination issue between acquisition and production planning, in which the proportional yield is stochastic and the core return is sensitive to the acquisition price in a hybrid manufacturing and remanufacturing system [22]. These studies assumed that the acquirable cores had been sorted, and each grade of cores was homogenous, that is, quality variability was not considered.

Quality variability implies that the quality of each acquirable core is assumed heterogeneous in a core acquisition. Some researchers have analyzed how core acquisition was influenced by quality variability. Galbreth and Blackburn developed an acquisition and sorting model with quality variability under both deterministic and uncertain demands [23]. Lu extended this model to two cases: the acquisition cost with a piecewise linear convex function and with a multi-period decision issue
[24]. Ferguson et al. examined a multi-period production planning problem facing different quality levels of cores [25]. These studies investigated the influence of quality variability. However, core condition is deterministic, that is, the proportional yield is deterministic. Some researchers have also discussed the effect of both condition uncertainty and quality variability on the decision process of core acquisition and remanufacturing $[26 \div 28]$. Detailed discussions and reviews can be obtained from [28, 29]. However, the environmental burdens in the remanufacturing process were not considered in the aforementioned papers.

Krikke studied the effect of carbon footprints on the design of a closed-loop network [30]. Kannan et al. developed a similar model [31]. Liu et al. developed distribution-free newsvendor models to determine the remanufacturing policies under three carbon emission regulations [3]. Yang et al. examined a multi-product acquisition and remanufacturing problem under a variable core quality and carbon tax scheme [12]. However, quantity discount was ignored in the aforementioned papers.

In the current paper, quantity discount is incorporated into the core acquisition problem. Moreover, carbon emission is a classic environmental burden. The effect of carbon emission is incorporated into the problem based on the carbon tax scheme. First, the problem, which considers quality variability, is studied and then extended under both condition uncertainty and quality variability. In the two cases, the problem is formulated as nonlinear mixed integer programming models. The properties of the models are analyzed, and the optimal solutions are derived by the effective approaches.

\section{Methodology}

\subsection{Problem descriptions and assumptions}

In this paper, the remanufacturer is assumed to acquire cores from third-party brokers or collectors in a market-driven remanufacturing system. Facing a deterministic demand $\mathrm{m}$, the remanufacturer determines the acquisition quantity $n(n \geq m)$ according to the quality of acquirable cores (shown in Fig. 2).

The remanufacturer should select the suitable indices and estimate the quality using historical data because the quality of each acquirable core $(t)$ is different and unknown before acquisition (i.e., quality variability). $t$ is usually measured by a continuous indicator, such as total running time in the entire machine lifetime [32], remanufacturing cost $[23,24]$, and remanufacturing process time (i.e., time required for remanufacturing) [33] The higher the value of $t$ is, the worse the quality. Here, $t$ is a random variable with the cumulative distribution function of $G(\cdot)$ and the probability density function of $g(\cdot)$. According to Galbreth and Blackburn, for a given $t$, the unit remanufacturing cost is $a+c t$, where $a$ is the unit fixed cost, and $c$ is a variable component that depends on core quality [26].

The remanufacturer provides a price schedule with price breaks at quantities $\left(q_{i}\right)$ to encourage brokers or collectors to offer adequate cores, where $0=q_{0}<q_{1}<q_{2}<\cdots<q_{l}=\infty$. If the acquisition quantity 
n satisfies $q_{i-1} \leq n<q_{i}(i=1,2, \ldots, l)$, the unit acquisition cost is $u_{i}$. In addition, $u_{1}>u_{2}>\cdots>u_{l}$.

In addition, many counties and economic communities have implemented a series of regulatory mechanisms to reduce carbon emission [34, 35]. The carbon tax scheme is a frequently used cost-effective measure. This paper incorporates carbon emission into the model under the carbon tax scheme.

After the cores are purchased, the remanufacturer selects the best $\mathrm{m}$ cores to be remanufactured. The remaining $n-m$ cores are scrapped because of poor quality with a unit scrapping costs. The notation used in this paper is as follows:

Parameters

$m$ - deterministic demand $k$-index of cores, $k=1,2, \ldots, m$

$i$ - index of discount segment, $i=1,2, \ldots, l$

$u_{i}-$ unit acquisition cost of discount segment $i$

$n_{i}-$ acquisition quantity of discount segment $i$

$s$ - unit scrapping cost

$t$ - quality of each core

$g(\cdot)$ - probability density function of quality

$G(\cdot)$ - cumulative distribution function of quality

$e-$ carbon emission of unit remanufactured product

$e_{s}-$ carbon emission of unit scrapped product

$c_{e}-$ carbon tax of unit carbon emission

\section{Decision variable}

$n$ - acquisition quantity

$y_{i}-0 \div 1$ variable. If cores are acquired at the discount segment $i, y_{i}=1$; otherwise, $y_{i}=0$.

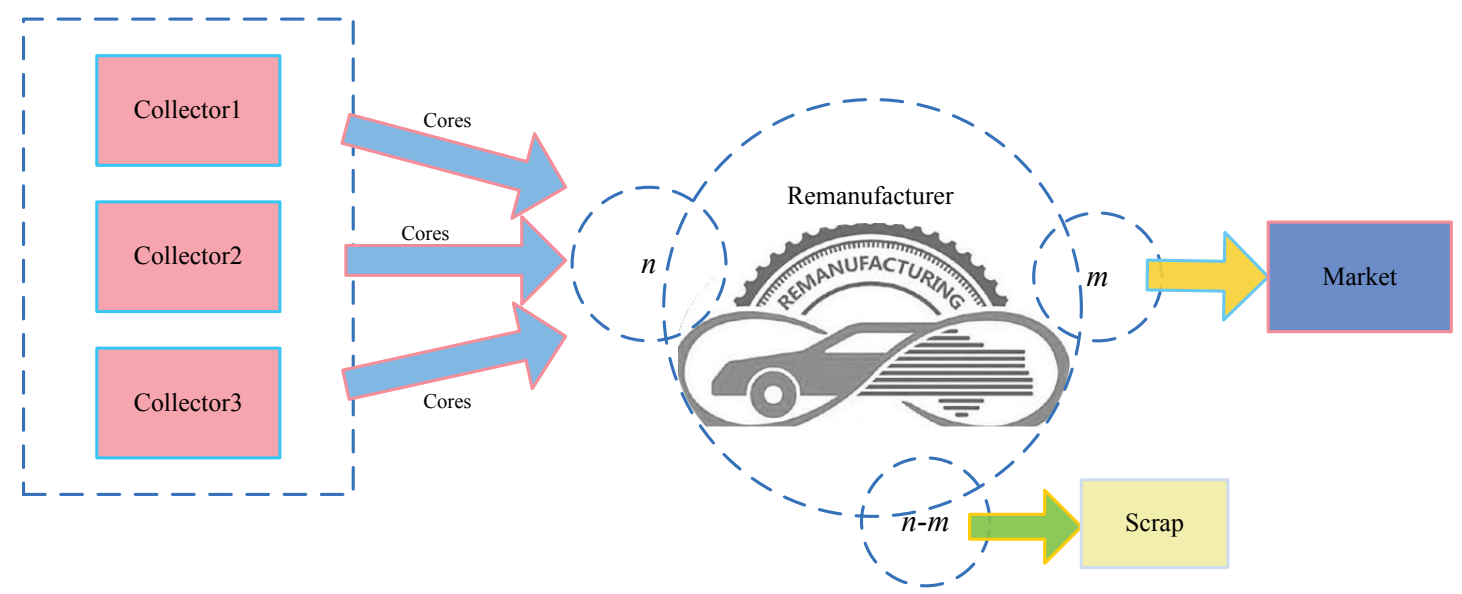

Figure 2 Process of acquiring and sorting cores

\subsection{Model with quality variability}

\subsubsection{Model formulation}

When the quality of the acquirable cores is estimated, the remanufacturer provides a threshold value $\left(t_{0}\right)$ and analyzes which acquirable core should be remanufactured or scrapped [23]. That is, the cores of high quality (i.e., $t \leq t_{0}$ ) are remanufactured and the cores in poor quality (i.e., $t>t_{0}$ ) are scrapped (shown in Fig. 3).

Accordingly, the expected remanufacturing rate is $G\left(t_{0}\right) \quad$ (i.e., $\left.\quad G\left(t_{0}\right)=\int_{0}^{t_{0}} g(t) \mathrm{d} t=\frac{m}{n}\right)$. For the given discount segment $i, G\left(t_{0, i}\right)=\int_{0}^{t_{0, i}} g(t) \mathrm{d} t=\frac{m}{n_{i}}$. Here, the average remanufacturing cost is: $r\left(t_{0}\right)=a+\frac{c \int_{0}^{t_{0}} \operatorname{tg}(t) \mathrm{d} t}{\int_{0}^{t_{0, i}} g(t) \mathrm{d} t}$.

The remanufacturer minimizes the total cost, which includes the acquisition, remanufacturing, scrapped, and carbon emission costs, to derive the optimal acquisition quantity. When the cores are acquired at the discount segment $i(i=1,2, \cdots, l)$, the total cost is given as

$$
\begin{aligned}
& T c_{i}\left(n_{i}\right)=u_{i} n_{i}+\left(c_{e} e_{s}+s\right)\left(n_{i}-m\right)+ \\
& +m\left(c_{e} e+a+\frac{c \int_{0}^{t_{0, i}} \operatorname{tg}(t) \mathrm{d} t}{\int_{0}^{t_{0, i}} g(t) \mathrm{d} t}\right) .
\end{aligned}
$$

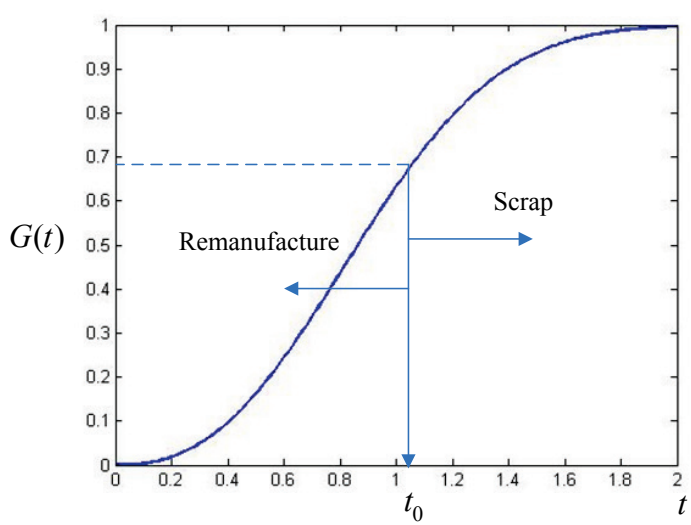

Figure 3 Core quality and sorting policy [23]

In Eq. (1), the first term is the acquisition cost, the second term is the scrapping cost, and the last term is the remanufacturing cost. Based on the above analysis, the model with quantity discount is given as:

(Model P1)

$$
\begin{aligned}
& \operatorname{Min} \operatorname{Tc}(n)=\sum_{i=1}^{l}\left\{u_{i} n_{i}+\left(c_{e} e_{s}+s\right)\left(n_{i}-m\right)+\right. \\
& \left.+m\left(c_{e} e+a+\frac{c \int_{0}^{t_{0, i}} \operatorname{tg}(t) \mathrm{d} t}{\int_{0}^{t_{0, i}} g(t) \mathrm{d} t}\right)\right\} y_{i},
\end{aligned}
$$


$n_{i}<q_{i} y_{i} \quad \forall i$

$n_{i} \geq q_{i-1} y_{i} \quad \forall i$

$\sum_{i=1}^{l} y_{i}=1$

$n=\sum_{i=1}^{l} n_{i} \geq m$

$n_{i}, n, m \in \mathrm{Z}^{+}$

$y_{i} \in\{0,1\} \quad \forall i$

In P1, Eq. (3) limits the upper bound of the acquisition quantity at the discount segment $i$, while Eq. (4) restricts the lower bound of the acquisition quantity at the discount segment $i$. Both (3) and (4) can be used to ensure the availability of discount segment $i$ because $y_{i}$ is a binary variable. Eq. (5) ensures the uniqueness of the discount segment. Eq. (6) means that the deterministic demand should be satisfied. Eq. (7) represents the integer constraints. The last constraints in Eq. (8) are binary constraints.

\subsubsection{Solution}

P1 is a mixed integer nonlinear programming problem. The properties of the model are further analyzed to solve the model effectively.

As $G\left(t_{0, i}\right)=m / n_{i}, T c_{i}\left(n_{i}\right)$ can be transformed as

$$
\begin{gathered}
T c_{i}\left(n_{i}\right)=m\left[\frac{u_{i}+\left(c_{e} e_{s}+s\right)\left(1-G\left(t_{0, i}\right)\right)+c \Lambda\left(t_{0, i}\right)}{G\left(t_{0, i}\right)}\right. \\
\left.+a+c_{e} e\right]=m A c\left(u_{i}, t_{0, i}\right)
\end{gathered}
$$

where, $\Lambda\left(t_{0, i}\right)=\int_{0, i}^{t_{0, i}} \operatorname{tg}(t) \mathrm{d} t$

$$
\begin{aligned}
A c\left(u_{i}, t_{0, i}\right)= & \frac{u_{i}+\left(c_{e} e_{s}+s\right)\left(1-G\left(t_{0, i}\right)\right)+c \Lambda\left(t_{0, i}\right)}{G\left(t_{0, i}\right)} . \\
& +a+c_{e} e
\end{aligned} .
$$

From Eq. (9), $A c\left(u_{i}, t_{0, i}\right)$ is easily identified as independent of $m[12,23] . A c\left(u_{i}, t_{0, i}\right)$ can be viewed as the average cost of remanufactured products in discount segment $i$. Here, the decision variable of $T c_{\mathrm{i}}\left(n_{\mathrm{i}}\right)$ is changed from the acquisition quantity $n_{i}$ to the threshold value $t_{0, i}$.

As shown above, the optimal solution of P1 can be derived in two steps.

Step 1: Deriving the optimal threshold value $t_{0}^{*}$.

Let $t_{0, i}^{*}$ be the minimal solution of $T c_{\mathrm{i}}\left(n_{\mathrm{i}}\right)$. On the basis of the first order condition of $T c_{\mathrm{i}}\left(n_{\mathrm{i}}\right)$, we can derive

$$
\left.\int_{0}^{t_{0, i}}\left(t_{0, i}-t\right) g(t) \mathrm{d} t\right|_{t_{0, i}=t_{0, i}^{*}}=\frac{u_{i}+c_{e} e_{s}+s}{c} .
$$

As the left-hand side of Eq. (10), $\int_{0}^{t_{0, i}}\left(t_{0, i}-t\right) g(t) \mathrm{d} t$, is a monotonically increasing function of $t_{0, i}, t_{0, i}^{*}$ can be determined by a single bisection method.

Here, the total cost is calculated as follows:

$T c_{i}\left(n_{i}\right)=m\left(a+c_{e} e+c t_{0, i}^{*}-c_{e} e_{s}-s\right)$

P1 can be viewed as the special case of [24]. The relationship between $t_{0, i}^{*}$ and $t_{0}^{*}$ is expressed as follows:

$t_{0}^{*}= \begin{cases}t_{0, i}^{*} & q_{i-1} G\left(t_{0, i}^{*}\right) \leq m<q_{i} G\left(t_{0, i}^{*}\right) \\ G^{-1}\left(m / q_{i}\right) & q_{i} G\left(t_{0, i}^{*}\right) \leq m<q_{i} G\left(t_{0, i+1}^{*}\right)\end{cases}$

Eq. (12) can be simplified because of the structure of the discount schedule in $\mathrm{P} 1$.

$G(\cdot)$ is the cumulative distribution function. From Eq. (10), we have:

$\left.\frac{\partial t_{0, i}}{\partial u_{i}}\right|_{t_{0, i}=t_{0, i}^{*}}=\frac{1}{G\left(t_{0, i}^{*}\right)}>0$.

That is, $t_{0, i}^{*}$ is the increasing function of $u_{i} \cdot A c\left(u_{i}, t_{0, i}^{*}\right)$ and $T c_{i}\left(n_{i}\right)$ are increasing functions of $u_{i}$ because of the monotonicity of $G_{i}(\cdot)$ and Eq. (11).

Thus, when $u_{1}>u_{2}>\cdots>u_{l}, t_{0,1}^{*}>t_{0,2}^{*}>\cdots>t_{0, l}^{*}$,

$G\left(t_{0,1}^{*}\right)>G\left(t_{0,2}^{*}\right)>\cdots>G\left(t_{0, l}^{*}\right)$,

$A c\left(u_{1}, t_{0,1}^{*}\right)>A c\left(u_{2}, t_{0,2}^{*}\right)>\cdots>A c\left(u_{l}, t_{0, l}^{*}\right)$, and

$T c_{1}\left(n_{1}\right)>T c_{2}\left(n_{2}\right)>\cdots>T c_{l}\left(n_{l}\right)$.

According to Eq. (12), if $q_{i-1} G\left(t_{0, i}^{*}\right) \leq m<q_{i} G\left(t_{0, i}^{*}\right)$, $t_{0}^{*}=t_{0, i}^{*}$. If $q_{i} G\left(t_{0, i+1}^{*}\right) \leq m<q_{i+1} G\left(t_{0, i+1}^{*}\right), t_{0}^{*}=t_{0, i+1}^{*}$.

When $q_{i} G\left(t_{0, i+1}^{*}\right) \leq m<q_{i} G\left(t_{0, i}^{*}\right), t_{0}^{*}=t_{0, i+1}^{*}$ because $G\left(t_{0, i}^{*}\right)>G\left(t_{0, i+1}^{*}\right)$ and $A c\left(u_{i}, t_{0, i}^{*}\right)>A c\left(u_{i+1}, t_{0, i+1}^{*}\right)$.

Furthermore, $q_{i} G\left(t_{0, i}^{*}\right) \leq m<q_{i} G\left(t_{0, i+1}^{*}\right)$ does not exist. Thus, Eq. (12) can be simplified, and the optimal threshold value $t_{0}^{*}$ is derived as follows:

$t_{0}^{*}=\left\{t_{0, i}^{*} \mid q_{i-1} G\left(t_{0, i}^{*}\right) \leq m<q_{i} G\left(t_{0, i+1}^{*}\right)\right\}$

Step 2: Determining the optimal acquisition quantity $n^{* *}$

After $t_{0}^{*}$ is derived, $n^{* *}$ can be determined through the expression $n^{* *}=m / G\left(t_{0}^{*}\right)$. 


\subsection{Model with both quality variability and condition uncertainty}

Section 3.2 only considers quality variability. That is, the remanufacturing rate $G\left(t_{0}\right)$ is deterministic, and the average cost of remanufactured products $A c\left(u_{i}, t_{0, i}\right)$ is independent of the acquisition quantity.

In this section, the model is extended to the case with both quality variability and condition uncertainty. Considering the condition uncertainty of acquirable cores, the remanufacturing rate $G\left(t_{0}\right)$ is stochastic. Furthermore, the higher the acquisition quantity is, the greater the choice of cores with higher quality. Therefore, the remanufacturing cost of the best $m$ cores is lower, that is, the average remanufacturing cost is related to the acquisition quantity. Here, let $X_{(1)}, X_{(2)}, \ldots, X_{(n)}$ denote the ascending order statistics of the $n$ cores, ordered by quality, and the corresponding quality are $t_{(1)}, t_{(2)}, \ldots, t_{(n)}$, and $t_{(1)} \leq t_{(2)} \leq \cdots \leq t_{(n)}$. Thus, the remanufacturing cost of the best $\mathrm{m}$ cores is expressed by $\sum_{k=1}^{m}\left(a+c t_{(k)}\right)$.

In addition, the other problem descriptions and assumptions of this model are the same as those in Section 3.2.

When the cores are acquired at the discount segment $i$ ( $i=1,2, \cdots, l$ ), the total cost is given as

$$
\begin{aligned}
& T c_{i}\left(n_{i}\right)=u_{i} n_{i}+\left(c_{e} e_{s}+s\right)\left(n_{i}-m\right)+\sum_{i=1}^{l}\left[c_{e} e+a+\right. \\
& +c \int_{0}^{\infty} t n_{i}\left(\begin{array}{c}
n_{i}-1 \\
k-1
\end{array}\right)\left(G(t)^{k-1}(1-G(t))^{n_{i}-k} g(t) \mathrm{d} t\right] .
\end{aligned}
$$

In Eq. (15), the first term is the acquisition cost, the second term is the scrapping cost, and the last term is the remanufacturing cost. Accordingly, the complete model with both condition uncertainty and quality variability is given as:

(Model P2)

$$
\begin{aligned}
& \operatorname{Min} \operatorname{Tc}(n)=\sum_{i=1}^{l}\left\{u_{i} n_{i}+\left(c_{e} e_{s}+s\right)\left(n_{i}-m\right)+\sum_{k=1}^{m}\left[c_{e} e+a+\right.\right. \\
& \left.+c \int_{0}^{\infty} t n_{i}\left(\begin{array}{c}
n_{i}-1 \\
k-1
\end{array}\right)\left(G(t)^{k-1}(1-G(t))^{n_{i}-k} g(t) \mathrm{d} t\right]\right\} y_{i}, \\
& \text { s.t. Eqs. (3) } \div(8) .
\end{aligned}
$$

P2 is also a mixed integer nonlinear programming problem. The properties of the model are analyzed to solve the model effectively.

First, the following model can be derived for discount segment $i(i=1,2, \cdots, l)$,

\section{(Model P3)}

$$
\begin{aligned}
& \operatorname{MinT}_{i}\left(n_{i}\right)=u_{i} n_{i}+\left(c_{e} e_{s}+s\right)\left(n_{i}-m\right)+\sum_{k=1}^{m}\left[c_{e} e+a+\right. \\
& +c \int_{0}^{\infty} t n_{i}\left(\begin{array}{c}
n_{i}-1 \\
k-1
\end{array}\right)\left(G(t)^{k-1}(1-G(t))^{n_{i}-k} g(t) \mathrm{d} t\right],
\end{aligned}
$$

$$
\begin{aligned}
& n_{i}<q_{i} \\
& n_{i} \geq q_{i-1} \\
& n_{i} \geq m \\
& n_{i}, m \in \mathrm{Z}^{+}
\end{aligned}
$$

$n^{* *}$ is the optimal solution of $\mathrm{P} 2$, and $n_{i}^{*}$ is the optimal solution of $\mathrm{P} 3$. Then, the minimal objective function value of $\mathrm{P} 2$ is

$$
\begin{aligned}
& T c\left(n^{* *}\right)=\min \left\{T c_{i}\left(n_{i}^{*}\right), i=1,2, \cdots, l\right\} \\
& n^{* *}=\arg \min \left\{T c_{i}\left(n_{i}^{*}\right), i=1,2, \cdots, l\right\}
\end{aligned}
$$

Let $n_{i}^{+}$be the optimal solution of P3 without constraints (18-19).

Carbon tax changes the remanufacturer's costs, but the properties of the problem are still similar to [28]. Thus, $n_{i}^{+}$can be derived on the basis of [28].

$$
\begin{aligned}
& n_{i}^{+}=\operatorname{Inf}\left\{n_{i} \mid \int_{0}^{1}\left(\Gamma\left(n_{i}-1, m, \lambda\right)-\Gamma\left(n_{i}, m, \lambda\right)\right) G^{-1}(\lambda) \mathrm{d} \lambda \leq\right. \\
& \left.\leq \frac{u_{i}+c_{e} e_{s}+s}{c}, n_{i} \in Z^{+}\right\}, \\
& n_{i}^{+}=\max \left\{m, n^{+}\right\}
\end{aligned}
$$

where, $\Gamma\left(n_{i}, m, \lambda\right)=n_{i} \sum_{k=1}^{m}\left(\begin{array}{c}n_{i}-1 \\ k-1\end{array}\right) \lambda^{k-1}(1-\lambda)^{n_{i}-k}$.

Furthermore, Yang et al. proved that $T c_{\mathrm{i}}\left(n_{\mathrm{i}}\right)$ is a strictly discrete convex function of $n_{i}\left(n_{i} \geq m\right)$ [28]. Based on the above research results, the relationship between $n_{i}^{+}$ and $n_{i}^{*}$ is analyzed as follows:

\section{Proposition 1}

(a) If $q_{i-1} \leq n_{i}^{+}<q_{i}$, then $n_{i}^{*}=n_{i}^{+}$;

(b) If $n_{i}^{+} \geq q_{i}$, then $n_{i}^{*}=q_{i}$;

(c) If $n_{i}^{+}<q_{i-1}$, then $n_{i}^{*}=q_{i-1}$.

Proof.

(a) The statement holds straightforwardly.

(b) $T c_{i}\left(n_{i}\right)$ is a strictly discrete convex function of $n_{i}$ $\left(n_{i} \geq m\right)$. Thus, $T c_{i}\left(n_{i}\right)$ monotonically decreases for $n_{i} \leq n_{i}^{+}$. We have $n_{i}^{*}=q_{i}$ because $n_{i}^{+} \geq q_{i}$.

(c) Similar to (b), $T c_{i}\left(n_{i}\right)$ monotonically increases for $n_{i}$ $\left(n_{i} \geq m\right)$. When $n_{i}^{+}<q_{i-1}$, we have $n_{i}^{*}=q_{i-1}$.

According to Proposition 1, the optimal solution of P2 (i.e., $n^{* *}$ ) can be derived by the following algorithm: Algorithm 1:

Step 1. Initialization: starting from the lowest unit acquisition cost, i.e., $i=l$. 
Step 2. If $i=0$, let $i=1$, and go to Step 5; else, calculate $n_{i}^{+}$by a single bisection method.

Step 3. Check the discount bound constraints: If $q_{i-1} \leq n_{i}^{+}<q_{i}$, then $n_{i}^{*}=n_{i}^{+}$, and go to Step 5 .

Step 4. If $n_{i}^{+} \geq q_{i}$, then $n_{i}^{*}=q_{i}$; otherwise $n_{i}^{*}=q_{i-1}$. Let $i=i-1$, and go to Step 2 .

Step 5. Compare the objective values of $n_{i}^{*}$, and choose the best as the solution of $\mathrm{P} 2$. That is, $T c\left(n^{* *}\right)=\min \left\{T c_{i}\left(n_{i}^{*}\right), i=j, j+1, \cdots, l\right\}$ and $n^{* *}=\arg \min \left\{T c_{i}\left(n_{i}^{*}\right), i=j, j+1, \cdots, l\right\}$.

In Step 2, $n_{i}^{+}$is calculated by a single bisection method from [28]. Solving P3 is unnecessary for all discount segments in the above algorithm. Without loss of generality, Algorithm 1 will stop in discount segment $j$ once $q_{j-1} \leq n_{j}^{+}<q_{j}$.

As $u_{i}>u_{i+1}, T c_{i+1}\left(n_{i}\right)<T c_{i}\left(n_{i}\right)$. Then,

$T c_{i+1}\left(n_{i+1}^{+}\right)<T c_{i+1}\left(n_{i}^{+}\right)<T c_{i}\left(n_{i}^{+}\right)$. Consequently,

$T c_{l}\left(n_{l}^{+}\right)<\cdots<T c_{i+1}\left(n_{i+1}^{+}\right)<T c_{i}\left(n_{i}^{+}\right)<\cdots<T c_{1}\left(n_{1}^{+}\right)$.

Therefore, we only calculate the objective values of $n_{i}^{*}$ with $i \geq j$ in Step 3 or 4 . When the minimal value is selected in Step 5, the corresponding solution is optimal to P2. In addition, Algorithm 1 can be applied to any continuous quality distribution because the quality distribution is not hypothesized.

Table 1 Optimal results of the model with quality variability (I)

\begin{tabular}{|c|c|c|c|c|c|}
\hline $\begin{array}{c}\text { Distribution } \\
\text { Parameters }\end{array}$ & $\begin{array}{c}\text { Discount } \\
\text { Segment }\end{array}$ & $\begin{array}{c}\text { Unit acquisition } \\
\text { costs }\left(u_{i}\right)\end{array}$ & $t_{0, i}^{*}$ & $A c\left(u_{i}, t_{0, i}\right)$ & $G\left(t_{0, i}^{*}\right)(\%)$ \\
\hline \multirow{2}{*}{$\begin{array}{c}\text { uniform } \\
(\alpha=1, \beta=3)\end{array}$} & {$[0,200]$} & 2,80 & 2,2247 & 17,6980 & 61,24 \\
\cline { 2 - 6 } & {$[200,300]$} & 2,65 & 2,1937 & 17,4499 & 59,69 \\
\cline { 2 - 6 } & {$[200, \infty]$} & 2,50 & 2,1619 & 17,1952 & 58,09 \\
\hline \multirow{2}{*}{$\begin{array}{c}\text { exponential } \\
(\mu=2)\end{array}$} & {$[0,200]$} & 2,80 & 1,3636 & 10,8086 & 49,43 \\
\cline { 2 - 7 } & {$[200,300]$} & 2,65 & 1,3253 & 10,5022 & 48,45 \\
\cline { 2 - 7 } & {$[200, \infty]$} & 2,50 & 1,2862 & 10,1892 & 47,43 \\
Weibull & {$[0,200]$} & 2,80 & 0,8436 & 6,6484 & 60,09 \\
\cline { 2 - 7 }$(\alpha=1, \beta=0.5)$ & {$[200,300]$} & 2,65 & 0,8122 & 6,3973 & 59,39 \\
\cline { 2 - 7 } & {$[200, \infty]$} & 2,50 & 0,7804 & 6,1432 & 58,66 \\
\hline
\end{tabular}

Table 2 Optimal results of the model with quality variability (II)

\begin{tabular}{|c|c|c|c|c|c|c|c|c|}
\hline \multirow{2}{*}{$\begin{array}{c}\text { Distribution } \\
\text { parameters }\end{array}$} & \multirow{2}{*}{\multicolumn{2}{|c|}{ Scenarios }} & \multicolumn{6}{|c|}{$M$} \\
\hline & & & 50 & 80 & 110 & 140 & 170 & 200 \\
\hline \multirow{6}{*}{$\begin{array}{c}\text { Uniform } \\
(\alpha=1, \beta=3)\end{array}$} & \multirow{3}{*}{ Discount } & $t_{0}^{*}$ & 2,2247 & 2,2247 & 2,2247 & 2,1937 & 2,1937 & 2,1619 \\
\hline & & $n^{* *}$ & 82 & 131 & 180 & 235 & 285 & 344 \\
\hline & & $T c\left(n^{* *}\right)$ & 885 & 1416 & 1947 & 2443 & 2966 & 3439 \\
\hline & \multirow{3}{*}{$\begin{array}{c}\text { Non- } \\
\text { discount }\end{array}$} & $t_{0}^{*}$ & 2,2247 & 2,2247 & 2,2247 & 2,2247 & 2,2247 & 2,2247 \\
\hline & & $n^{* *}$ & 82 & 131 & 180 & 229 & 278 & 327 \\
\hline & & $T c\left(n^{* *}\right)$ & 885 & 1416 & 1947 & 2478 & 3009 & 3540 \\
\hline \multirow{6}{*}{$\begin{array}{l}\text { Exponential } \\
(\mu=2)\end{array}$} & \multirow{3}{*}{ Discount } & $t_{0}^{*}$ & 1,3636 & 1,3636 & 1,3253 & 1,3253 & 1,2862 & 1,2862 \\
\hline & & $n^{* *}$ & 101 & 162 & 227 & 289 & 358 & 422 \\
\hline & & $T c\left(n^{* *}\right)$ & 540 & 865 & 1155 & 1470 & 1732 & 2038 \\
\hline & \multirow{3}{*}{$\begin{array}{c}\text { Non- } \\
\text { discount }\end{array}$} & $t_{0}^{*}$ & 1,3636 & 1,3636 & 1,3636 & 1,3636 & 1,3636 & 1,3636 \\
\hline & & $n^{* *}$ & 101 & 162 & 223 & 283 & 344 & 405 \\
\hline & & $T c\left(n^{* *}\right)$ & 540 & 865 & 1189 & 1513 & 1837 & 2162 \\
\hline \multirow{6}{*}{$\begin{array}{l}\text { Weibull } \\
(\alpha=1, \\
\beta=0.5)\end{array}$} & \multirow{3}{*}{ Discount } & $t_{0}^{*}$ & 0,8436 & 0,8436 & 0,8436 & 0,8122 & 0,8122 & 0,7804 \\
\hline & & $n^{* *}$ & 83 & 133 & 183 & 236 & 286 & 341 \\
\hline & & $T c\left(n^{* *}\right)$ & 332 & 532 & 731 & 896 & 1088 & 1229 \\
\hline & \multirow{3}{*}{$\begin{array}{c}\text { Non- } \\
\text { discount }\end{array}$} & $t_{0}^{*}$ & 0,8436 & 0,8436 & 0,8436 & 0,8436 & 0,8436 & 0,8436 \\
\hline & & $n^{* *}$ & 83 & 133 & 183 & 233 & 283 & 333 \\
\hline & & $T c\left(n^{* *}\right)$ & 332 & 532 & 731 & 931 & 1130 & 1330 \\
\hline
\end{tabular}

\section{Result analysis and discussion \\ 4.1 Parameter setting}

Most of the parameters in the numerical examples are based on [28]. A third-party broker or collector is assumed to offer three discount segments: (1) smaller than 200, (2) between 200 and 299, and (3) larger than 300 with unit acquisition costs of 2,80, 2,65 and 2,50, respectively. Other parameters are set to the following: $s$ $=0, a=0, c=8, e=0,1, e_{s}=0,2, c_{e}=1$.

The case without quantity discount is considered to analyze the effects of quantity discount. In non-discount case, $u=2,8$. The results in the numerical examples are analyzed under frequently used quality distributions (i.e. 
uniform, exponential, and Weibull distributions). The means of the different distributions are assumed to be 2 .

\subsection{Effect of quantity discount}

For the model with quality variability, the optimal results are shown in Tabs. 1 and 2.

In Tab. 1, the optimal acquisition threshold value of the given discount segment $\left(t_{0, i}^{*}\right)$ is derived by Eq. (10) under three distributions. Accordingly, the average costs of the remanufactured products $\left(A c\left(u_{i}, t_{0, i}\right)\right)$, and the remanufacturing rate $\left(G\left(t_{0, i}^{*}\right)\right)$ are calculated.

Based on the above results, the optimal threshold value $\left(t_{0}^{*}\right)$ is derived by Eq. (14). The optimal acquisition quantities $\left(n^{* *}\right)$ and the total costs are calculated under different demands (shown in Tab. 2).

Tab. 2 compares the optimal acquisition policy under the discount and non-discount cases. In the discount case, the remanufacturer can acquire more cores and select more high-quality cores because unit acquisition cost decreases, thus resulting in the decrease in the threshold value and the remanufacturing ratio. Accordingly, the average cost of remanufactured products and the total cost decrease (e.g. the optimal results in the Weibull distribution). Tab. 2 illustrates that when only quality variability is considered, the threshold value may decrease by up to $7,49 \%((0,8436-0,7804) / 0,8436)$, the acquisition quantity may increase by up to $2,35 \%((341-333) / 341)$, and the total cost may decrease by up to $7,59 \%$ $((1330-1229) / 1330)$. The total cost decreases by $2,51 \%$ on average.

For the model with both the quality variability and the condition uncertainty, the optimal results under different distributions are shown in Figs. $4 \div 6$.

According to Tab. 2 and Figs 4-6, the remanufacturer can similarly acquire more cores in the case with both the quality variability and the condition uncertainty. Unlike in the case with the quality variability, the remanufacturing ratio is no longer decreasing monotonously. Given the demand $(m)$, the optimal acquisition quantity may be more than that in the case with quality variability, and the total cost declines (e.g., the optimal results in the Weibull distribution). Fig. 6 illustrates that the acquisition quantity may increase by up to $2,34 \%((342-334) / 342)$, and that the total cost will decrease by up to $7,57 \%$ ((1334-1233)/1334). The total cost decreases by 3,63\% on average.

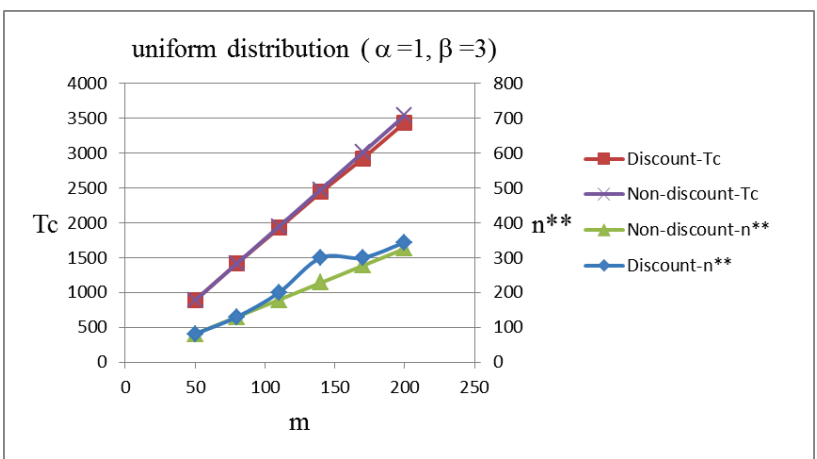

Figure 4 Optimal results under the uniform distribution

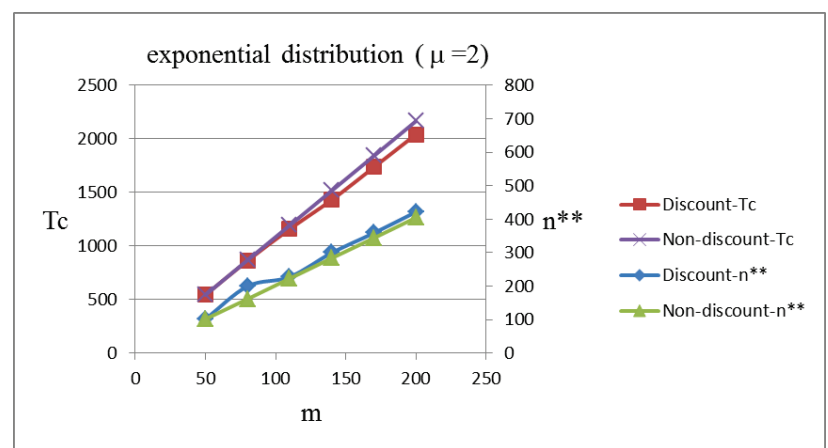

Figure 5 Optimal results under the exponential distribution

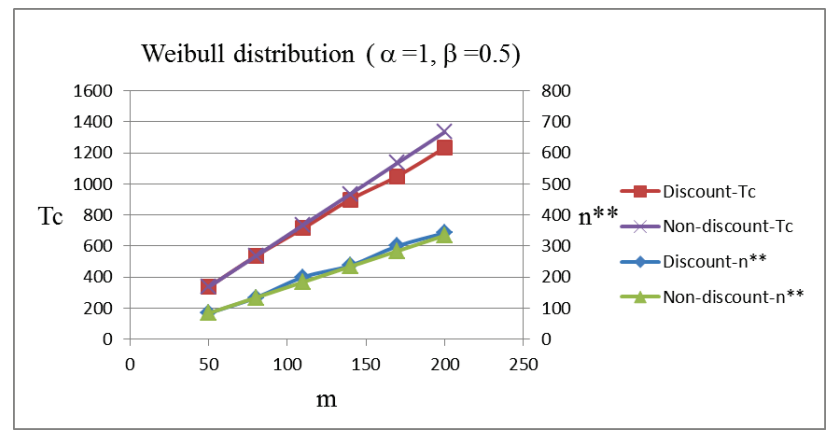

Figure 6 Optimal results under the Weibull distribution

\section{Conclusions}

The nonlinear mixed integer programming models were established under the quantity discount and carbon tax scheme to reduce the operation and management difficulties caused by high uncertainty and variability of acquirable cores. The following conclusions were obtained:

(1) When quality variability is considered, the average cost of the remanufactured products is independent of the acquisition quantity for the given discount segment. The optimal acquisition solution is derived in the closed-form expression.

(2) When both the quality variability and the condition uncertainty are considered, the total expected cost is strictly a discrete convex function of acquisition quantity for the given discount segment. The optimal acquisition solution is derived on the basis of the bisection method.

(3) The case studies considered in current paper verify that the quantity discount schedule can encourage remanufacturers to acquire more cores and effectively reduce the total expected cost, especially in the case with both the quality variability and the condition uncertainty.

This study can be extended to the case with stochastic demand. Moreover, the multi-product acquisition problem with quantity discount is worth studying.

\section{Acknowledgement}

The study was supported by the National Social Science Foundation of China (12CGL045) and the China Postdoctoral Science Foundation (2013M531541).

\section{References}

[1] Guide, V. D. R. Jr.; Van Wassenhove, L. N. The Evolution of Closed-Loop Supply Chain Supply Chain Research. // 
Operations Research. 57, 1 (2009), pp. 10-18. DOl: 10.1287/opre.1080.0628

[2] Van Wassenhove, L. N.; Zikopoulos, C. On the effect of quality overestimation in remanufacturing. // International Journal of Production Research. 48, 18(2010), pp. 52635280. DOI: 10.1080/00207540903150585

[3] Liu, B.; Holmbom, M.; Segerstedt, A.; Chen, W. Effects of carbon emission regulations on remanufacturing decisions with limited information of demand distribution. // International Journal of Production Research. 53, 2(2015), pp. 532-548. DOI: 10.1080/00207543.2014.957875

[4] Smith, V. M.; Keoleian, G. A. The value of remanufactured engines: life-cycle environmental and economic perspectives. // Journal of Industrial Ecology. 8, 1-2(2004), pp. 193-221.

[5] Sundin, E. Product and Process Design for Successful Remanufacturing, in Production Systems Dissertation. Department of Mechanical Engineering, Linköping University, Linköping, Sweden, 2004.

[6] Guide, V. D. R. Production planning and control for remanufacturing: industry practice and research needs. // Journal of Operations Management. 18, 4(2000), pp. 467483. DOI: $10.1016 / \mathrm{S} 0272-6963(00) 00034-6$

[7] Guide, V. D. R.; Jayaraman, V. Product acquisition management: current industry practice and a proposed framework. // International Journal of Production Research. 38, 16(2000), pp. 3779-3800. DOI: 10.1080/00207540050176003

[8] Aras, N.; Boyaci, T.; Verter, V. The effect of categorizing returned products in remanufacturing. // IIE Transactions. 36, (2004), pp. 319-331. DOI: 10.1080/07408170490279561

[9] Galbreth, M. R.; Blackburn, J. D. Offshore remanufacturing with variable used product condition. // Decision Sciences. 41, 1(2010b), pp. 5-20. DOI: 10.1111/j.15405915.2009.00257.x

[10] Guide, V. D. R.; Van Wassenhove, L. N. Managing product returns for remanufacturing. // Production and Operations Management. 10, 2(2001), pp. 142-155. DOI: 10.1111/j.19375956.2001.tb00075.x

[11] Loomba, A. P. S.; Nakashima, K. Enhancing value in reverse supply chains by sorting before product recovery. // Production Planning \& Control: The Management of Operations. 23, 2-3(2012), pp. 205-215. DOl: 10.1080/09537287.2011.591652

[12] Yang C. H.; Liu H. B.; Ji, P.; Ma, X. Optimal acquisition and remanufacturing policies for multi-product remanufacturing systems. // Journal of Cleaner Production. (2016), pp. 1-9. DOI: 10.1016/j.jclepro.2015.10.057

[13] Cai, X. Q.; Lai, M. H.; Li, X.; Li, Y. J.; Wu, X.Y. Optimal acquisition and production policy in a hybrid manufacturing/remanufacturing system with core acquisition at different quality levels. // European Journal of Operational Research. 233, 2(2014), pp. 374-382. DOI: 10.1016/j.ejor.2013.07.017

[14] Guide, V. D. R.; Teunter, R. H.; Van Wassenhove, L. N. Matching demand and supply to maximize profits from remanufacturing. // Manufacturing \& Service Operations Management. 5, 4(2003), pp. 303-316. DOl: $10.1287 / \mathrm{msom} \cdot 5.4 .303 .24883$

[15] Jena, S. K.; Sarmah, S. P. Optimal acquisition price management in a remanufacturing system. // International Journal of Sustainable Engineering. 7, 2(2014), pp. 154170. DOI: $10.1080 / 19397038.2013 .811705$

[16] Minner, S.; Kiesmuller, G. P. Dynamic product acquisition in closed loop supply chains. // International Journal of Production Research. 50, 11(2012), pp. 2836-2851. DOl: 10.1080/00207543.2010.539280

[17] Ovchinnikov, A. Revenue and cost management for remanufactured products. // Production and Operations
Management. 20, 6(2011), pp. 824-840. DOI: 10.1111/j.19375956.2010.01214.x

[18] Vadde, S.; Kamarthi, S. V.; Gupta, S. M. Optimal pricing of reusable and recyclable components under alternative product acquisition mechanisms. // International Journal of Production Research. 45, 18-19(2007), pp. 4621-4652. DOI: 10.1080/00207540701449973

[19] Zhou， S. X.; Yu， Y. K. Optimal product acquisition, pricing, and inventory management for systems with remanufacturing. // Operations Research. 59, 2(2011), pp. 514-521. DOI: $10.1287 /$ opre. 1100.0898

[20] Zikopoulos, C.; Tagaras, G. Impact of uncertainty in the quality of returns on the profitability of a single-period refurbishing operation. // European Journal of Operational Research. 182, 1(2007), pp. 205-225. DOI: 10.1016/j.ejor.2006.10.025

[21] Zikopoulos, C.; Tagaras, G. On the attractiveness of sorting before disassembly in remanufacturing. // IIE Transactions. 40, 3(2008), pp. 313-323. DOI: 10.1080/07408170701488078

[22] Li, X.; Li, Y. J.; Saghafian, S. A hybrid manufacturing/ remanufacturing system with random remanufacturing yield and market-driven product acquisition. // IEEE Transactions on Engineering Management. 60, 2 (2013), pp. 424-437. DOI: 10.1109/TEM.2012.2215873

[23] Galbreth, M. R.; Blackburn, J. D. Optimal acquisition and sorting policies for remanufacturing. // Production and Operations Management. 15, 3(2006), pp. 384-392. DOI: 10.1111/j.1937-5956.2006.tb00252.x

[24] Lu, Y. H. Optimal acquisition and sorting policies for remanufacturing over single and multiple periods. // Master Thesis, University of Massachusetts-Amherst, 2009.

[25] Ferguson, M.; Guide, V. D. R.; Koca, E.; Souza, G. C. The value of quality grading in remanufacturing. // Production and Operations Management. 18, 3(2009), pp. 300-314. DOI: $10.1111 / j .1937-5956.2009 .01033 . x$

[26] Galbreth, M. R.; Blackburn, J. D. Optimal acquisition quantities in remanufacturing with condition uncertainty. // Production and Operations Management. 19, 1(2010a), pp. 61-69. DOI: 10.1111/j.1937-5956.2009.01067.x

[27] Teunter, R. H.; Flapper, S. D. P. Optimal core acquisition and remanufacturing policies under uncertain core quality fractions. // European Journal of Operational Research. 210, 2(2011), pp. 241-248. DOI: 10.1016/j.ejor.2010.06.015

[28] Yang, C. H.; Wang, J.; Ji, P. Optimal acquisition policy in remanufacturing under general core quality distributions. // International Journal of Production Research. 53, 5(2015), pp. 1425-1438. DOI: 10.1080/00207543.2014.944283

[29] Panagiotidou, S.; Nenes, G.; Zikopoulos, C. Optimal procurement and sampling decisions under stochastic yield of returns in reverse supply chains. // OR Spectrum. 35, 1(2013), pp. 1-32. DOI: 10.1007/s00291-010-0234-z

[30] Krikke, H. Impact of closed-loop network configurations on carbon footprints: A case study in copiers. // Resources, Conservation and Recycling. 55, 12(2011), pp. 1196-1205. DOI: 10.1016/j.resconrec.2011.07.001

[31] Kannan, D.; Diabat, A.; Alrefaei, M.; Govindan, K.; Yong, G. A carbon footprint based reverse logistics network design model. // Resources, Conservation and Recycling. 67, (2012), pp. 75-79. DOI: 10.1016/j.resconrec.2012.03.005

[32] Simon, M.; Bee, G.; Moore, P.; Pu, J. S.; Xie, C. W. Modelling of the life cycle of products with data acquisition features. // Computers in Industry. 45, 2(2001), pp. 111122. DOI: $10.1016 / \mathrm{S} 0166-3615(01) 00088-4$

[33] Guide, V. D. R.; Gunes, E. D.; Souza, G. C.; Van Wassenhove, L. N. The optimal disposition decision for product returns. // Operations Management Research. 1, 1(2008), pp. 6-14. DOI: 10.1007/s12063-007-0001-8

[34] Milewski, J.; Lewandowski, J.; Miller, A. Reducing CO2 emissions from a gas turbine power plant by using a molten 
carbonate fuel cell. // Chemical and Process Engineering. 29, 4 (2008), pp.939-954.

[35] Kotowicz, J.; Lukowicz, P. Influence of chosen parameters on economic effectiveness of a supercritical combined heat and power plant. // Journal of Power Technologies. 93, 5(2013), pp. 323-329.

\section{Authors' addresses}

Cheng-Hu Yang, PhD, Associate Professor

School of Economics \& Management, Fuzhou University,

Room 301, No. 2 Xueyuan Road, Fuzhou, 350108, FuJian

Province, P. R. China

E-mail: hcysun@fzu.edu.cn

Xiao-Ying Bao, PhD, Associate Professor (Corresponding author)

College of Management Science, Chengdu University of

Technology, Room 9C501, No. 1 East 3 Road, Erxian Bridge,

Chengdu, 610059, Sichuan Province, P. R. China

E-mail: baoxiaoying205@163.com

Cong Song, MSc

School of Economics \& Management, Fuzhou University,

Room 301, No. 2 Xueyuan Road, Fuzhou, 350108, FuJian

Province, P. R. China

E-mail: songcong1234@126.com

Hai-Bo Liu, PhD candidate

Marketing Discipline Group, Business School, University of

Technology Sydney,

Building 8, 14-28 Ultimo Road, Ultimo, NSW, 2007, Australia

E-mail: Haibo.Liu@student.uts.edu.au 